\title{
Tajemnica obrazu. Czescy pisarze prowadzą śledztwo w świecie sztuki
}

Anna Gawarecka

\begin{abstract}
Proszę pana, wszystko jest zagadkowe oprócz przypadków kryminalnych; taki przypadek kryminalny stanowi precyzyjnie wyodrębniony fragment rzeczywistości, taki jej wycinek, na który skierowaliśmy światło ${ }^{1}$.
\end{abstract}

Reguły konstrukcyjne literatury kryminalnej doczekały się licznych opisów, opracowań i rekapitulacji. Nierzadko jednak deskrypcje te zatrzymują się na poziomie stereotypowych ustaleń, z jednej strony lokalizując prozę sensacyjną w obrębie pisarstwa popularnego i powielając tezy o jego schematyczności i predylekcji do rutynowych, a priori przewidywalnych rozwiązań, z drugiej strony zaś, jak to w radykalnym geście uczynił Roger Caillois, usuwając tę prozę, ze względu na jej stricte intelektualny, „łamigłówkowy” charakter, poza granice, najszerzej nawet pojmowanej, literackości². Badacz stosuje ten ostracystyczny manewr po to

\footnotetext{
${ }^{1}$ K. Čapek, Povídky z jedné kapsy, Praha 1985, s. 110. Przekład wszystkich cytatów z języka czeskiego: A.G.

2 By zdemaskować sprawcę zbrodni, należy bowiem, twierdzi badacz, „oddzielić od reszty świata pewne ludzkie środowisko, zapobiec wszelkim zewnętrznym interwencjom lub przeciekom, wzbronić sobie tłumaczenia czegokolwiek działaniem tajemniczego a potężnego deus ex machina, podać wreszcie wszystkie przesłanki, które przyczyniły się do powstania skandalu i które trzeba znać, aby móc go wyjaśnić. Skoro te warunki zostają spełnione, nic w istocie nie różni powieści kryminalnej od zadania matematycznego. [...] Powieść kryminalna przestaje więc w końcu zasługiwać na nazwę powieści. U kresu swej ewolucji ukazuje też swoją prawdziwą naturę. Nie jest opowieścią, ale zadaniem" (R. Caillois, Powieść kryminalna czyli Jak intelekt opuszcza świat, aby oddać się li tylko grze, i jak społeczeństwo wprowadza z powrotem swe problemy w igraszki umysłu, przeł. J. Błoński, [w:] R. Caillois, Odpowiedzialność i styl, Warszawa 1967, s. 191). Za przykład podtrzymywania tezy o „obligatoryjnie” szablonowym charakterze konstrukcji (tematycznej i narracyjnej) powieści kryminalnej posłużyć zaś mogą słowa E. Mrowczyk-Hearfield: „Wstępnie można więc, jak sądzę, przyjąć, że literatura kryminalna byłaby twórczością, która w centrum swoich zainteresowań stawia zagadnienie zbrodni czy, ogólniej rzecz ujmując, przestępstwa, oraz drogi wiodącej do rozwiązania zagadki owego przestępstwa. Jest to literatura, która nie stosuje motywów kryminalnych jedynie jako pretekstu do rozwinięcia innych kwestii, choć często (ze względu na specyfikę tematu) porusza też zagadnienia moralne (stawiając je jednak zawsze na planie drugim, na pierwszym pozostawiając zagadkę). Literatura ta nie ma charakteru mitycznego ani sakralnego (nie rozstrzyga problemów grzechu i kary za grzech), choć traktuje o walce dobra ze złem. Jest pisana metodą realistyczną, a jej cechą charakterystyczną jest wyraźne sformalizowanie fabuły oraz budowanie kompozycji linearnej z wątkami biegnącymi w przód i wstecz" (E. Mrowczyk-Hearfield, Badania literatury kryminalnejpropozycja, „Teksty Drugie” 1998, nr 6 (54), s. 97-98).
} 
(a podobne konkluzje formułował już w latach dwudziestych, niesłusznie w polskich opracowaniach pomijany, Karel Čapek³), by - w pierwszym rzędzie - zaprezentować modelowy inwariant gatunku, oczyszczony ze wszelkich zewnętrznych naleciałości zakłócających „szaradziarski" wymiar konstrukcji fabularnej i w konsekwencji ukazać, że literatura kryminalna, osiągnąwszy stan swoistej emocjonalnej jałowości, powróciła „do zwykłej powieści, bezładnej i bujnej, gdzie nie ma już ani odwrócenia chronologii, ani logicznego wynikania, ani rekonstrukcji zaszłego uprzednio wydarzenia. Narracja tyle ma tylko wspólnego z powieścią kryminalną, że się z niej niewątpliwie narodziła - dzięki podkreśleniu sensacyjnych cech detective novel, dzięki roli, jaką pełnią bandyci i detektywi, dzięki miejscu wreszcie, jakie w intrydze zajmują nagłe zgony i morderstwa z premedytacją. To, co było pretekstem i punktem wyjścia, stało się teraz najistotniejsze. Wzruszenie przeważyło znów refleksję. Obraz gwałtu wziął górę nad trudem oderwanego rozumowania" kryminalnej zatoczyły pełny niemal ewolucyjny krąg i - reaktywując elementy wyeliminowane w wyniku abstrahowania atrybutów gatunkowych - przywróciły tej prozie (potencjalnie przynajmniej) prawo do miejsca w świecie „wysokich” wartości literackich, wśród których, po długim okresie podejrzliwego (nomen omen) czy lekceważącego traktowania, zabójstwo, jako odwieczny, najbardziej niepokojący i bezwarunkowo potępiany znak transgresji w stosunkach międzyludzkich, odzyskało rangę „wielkiego tematu kultury”. Dzisiejszy, skrzętnie zresztą zarejestrowany przez badaczy, renesans tej literatury odbywa się jednak w odmiennej atmosferze kulturowej i nie może już, bezkarnie, chciałoby się powiedzieć, polegać na kopiowaniu pierwotnych założeń genologicznych bez narażania się na zarzuty anachroniczności i naiwnej wiary w niewygasającą atrakcyjność utartych rozwiązań fabularnych i narracyjnych. Z jednej strony bowiem postmodernistyczna akceptacja dla prowadzenia „gier z tandetą", ujmowania jej wyróżników w cudzysłów czy brania w nawias powagi, prawdopodobieństwa i mimetycznej iluzyjności konstrukcyjnych szablonów pozwala przenosić „na wyższy poziom zapośredniczenia" opowieści o przestępstwie i śledztwie, eksponując sztuczność i umowny wymiar przedstawianej rzeczywistości, z drugiej strony zaś - zauważalna nadreprezentacja tych opowieści na rynku wydawniczym podpowiada, by, za Anną Gemrą, zapytać, „co, jeśli nie ukazanie zbrodni i zagadka kryminalna, jest najważniejszym bądź jednym z najważniejszych celów autorów współczesnych kryminalnych powieści sensacyjno-awanturniczych; do czego wykorzystują [oni] konwencje i strukturę powieści kryminalnej"5. W obu wypadkach rozważenie przyczyn i konsekwencji tej „wzmożonej obecności” uwzględniać musi zarówno namysł nad wtórną funkcjonalizacją motywów składających się na standardowy zasób tematyczny kryminału, jak i pozwala na wyeksponowanie rozmaitych strategii pisarskich wiodących ku ożywieniu spetryfikowanych schematów i nadaniu im zaskakujących walorów

\footnotetext{
${ }^{3}$ Por.: „Detektivka (míním zde čistou detektivku a nikoli odrůdy smíšené s románem pasionálním, literárními ambicemi a jinými kontaminujícími vlivy) je literární úkaz stejně jednoduchý jako dejme tomu epická báseň nebo dětská báchorka. [...] Zdá se opravdu, že detektivka už překročila svůj vrchol; byla to jakási přechodná móda. Avšak na každé pomíjivé módě je pozoruhodné to, že obsahuje něco strašně starého" (K. Čapek, Holmesiana čili o detektivkách, [w:] tenże, Marsyas čili Na okraj literatury (1919-1931), Praha 1971, s. 142-143, 156).

${ }^{4}$ R. Caillois, Powieść kryminalna..., s. 202-203.

${ }^{5}$ A. Gemra, Diagnoza rzeczywistości: wspótczesna powieść kryminalna sensacyjno-awanturnicza (na przykładzie powieści skandynawskiej), [w:] Śledztwo w sprawie gatunków. Literatura kryminalna, red. A. Gemra, Kraków 2014, s. 51. Jakub Z. Lichański stwierdza zaś wprost, że ,intryga kryminalna/sensacyjna jest tylko maską, konwencją; autorzy tak naprawdę opisują zupełnie inne problemy" (J.Z. Lichański, Współczesna powieść kryminalna: powieść sensacyjna czy powieść społeczno-obyczajowa? Próba opisu zjawiska (i ewolucji gatunku), [w:] Śledztwo w sprawie gatunków..., s. 20.)
} 
semantycznych ${ }^{6}$. Gra z konwencjami przeradza się dzięki temu w polemikę z „horyzontem oczekiwań" czytelnika, a popularna rozrywka zamiast bezinteresownych ludycznych atrakcji inspirować zaczyna do etycznych, społecznych lub kulturowych rozmyślań.

Od czasu, gdy Umberto Eco w Imieniu róży postanowił ożywić najbardziej „klasyczną” Conandoyle’owską - matrycę strukturalną powieści detektywistycznej, uzasadniając tę decyzję epistemologicznym potencjałem gatunku i jednocześnie wzbogacając repertuar jego konstytutywnych komponentów o "gotyckie” w swej proweniencji kategorie grozy, niesamowitości i makabry po to (między innymi oczywiście), by zadać pytanie o uniwersalną aktualność średniowiecznych dysput teologicznych, w literaturze światowej mnożą się przykłady tekstów wykorzystujących popularne schematy thrillera „ubarwiane” lokalizowaniem fabuły w rozmaitych „specjalistycznych” lub/i egzotycznych środowiskach. W kolejnych dziełach czy w twórczości różnych autorów zmienia się porządek ważności poszczególnych płaszczyzn, czysta „rozrywkowość” bierze górę nad ambicjami poznawczymi czy nad dążeniem do diagnozowania mankamentów współczesnego życia społecznego i politycznego. Jedno przy tym pozostaje niezmienne: fascynacja czytelników artystycznymi (literackimi, teatralnymi, filmowymi, intermedialnymi) strategiami wyjaśniania tajemnic i rozwiązywania zagadek. Jak bowiem konstatuje Umberto Eco, „ludzie lubią kryminały nie dlatego, że tam są trupy zamordowanych, ani dlatego, że sławi się tam triumf końcowego ładu (intelektualnego, społecznego, prawnego i moralnego) nad nieładem przestępstwa. Rzecz w tym, że powieść kryminalna przedstawia w stanie czystym historię domysłów. [...] W gruncie rzeczy podstawowe pytanie filozofii (podobnie jak psychoanalizy) brzmi tak samo jak powieści kryminalnej: Kto zawinił? Chcąc się tego dowiedzieć (chcąc zyskać przekonanie, że się wie), trzeba przypuścić, że wszystkie fakty mają jakąś logikę, logikę, którą narzucił im winowajca. [...] Staje się teraz jasne, czemu mój główny wątek (kim jest morderca?) rozgałęzia się na tyle innych, a wszystkie są historiami innych wątków, wszystkie obracają się wokół struktury domysłu jako takiego"7. Jak wiadomo, w Imieniu róży owo przypuszczenie, że logiką faktów świadomie i z premedytacją zarządza sprawca szeregu zbrodni, zostaje przekonująco zakwestionowane, a - wymagana przez reguły gatunku - „żelazna” kauzalność zdarzeń okazuje się pozorna. Ten, wywodzony z twórczości Friedricha Dürrenmatta, kierunek odnowy skostniałych konwencji gatunku, polegający na podaniu w wątpliwość leżących u jego podłoża iluzji poznawczych i wiary w „zbawienną moc” dedukcji, nie wyczerpuje wszystkich możliwości reaktualizacyjnych. Odrębna, choć nierzadko komplementarna w stosunku do linii epistemologicznej i przez Eco skwapliwie wykorzystana, możliwość poszerza-

\footnotetext{
${ }^{6}$ Zdaniem Magdaleny Lachman: „Przy okazji podobnych praktyk naruszane są powierzchniowe właściwości zniekształcanego komunikatu [...]. A jego zastosowanie staje się sprzeczne z pierwotnym (i często nadal typowym) użyciem. Aktywność pisarska sprowadza się zatem do konsekwentnego destruowania zapożyczonej materii bez kuszenia się o respektowanie jej kulturowej pozycji. Ma to z założenia prowokacyjny wymiar, ponieważ pokazuje, że każdy przekaz może zostać sprowadzony do poziomu zdefunkcjonalizowanego tworzywa” (M. Lachman, Gry z „tandeta” w prozie polskiej po 1989 roku, Kraków 2004, s. 191). Teresa Cieślikowska przypomina zaś, że: „Oddziaływanie powieściopisarstwa kryminalnego na współczesną prozę narracyjną nie sprowadza się [...] do transpozycji motywu zbrodni czy innego kryminalnego tematu. Dokonywa się ono w bardziej sensownych wymiarach i w skali uwarunkowanej doświadczeniami społecznego, naukowego i kulturowego rozwoju, w pełnej adaptacji zarówno osiągnięć, jak i ujemnych efektów kultury współczesnej. Odkrywanie niewiadomego i nieznanego, badanie tajemnic to niezawodny bodziec i tak jak wszelkie poznawanie, stanowi zawsze atrakcyjny cel działania. Powieść kryminalna funkcjonuje w tej roli jako miniaturka, która wyraża i reprezentuje (w miarę jej możliwości), a i zaspokaja pewien kompleks społecznych potrzeb. [...] To, co z powieściopisarstwa przenika do innych powieści, to już nie sam temat, ale sprawdzone miarą powodzenia osiągnięcia strukturalne" (T. Cieślikowska, Struktura powieści kryminalnej na tle wspótczesnego powieściopisarstwa, [w:] tejże, W kręgu genologii, intertekstualności, teorii sugestii, Warszawa-Łódź 1995, s. 77).

${ }^{7}$ U. Eco, Dopiski na marginesie Imienia róży, przeł. A. Szymanowski, [w:] U. Eco, Imię róży, przeł. A. Szymanowski, Warszawa 1990, s. 612-613.
} 
nia zespołu genologicznych atrybutów powieści kryminalnej polega na sięganiu po konwencje literatury gotyckiej i tzw. mystery novels, a zatem na wzbogacenia jej strategii kreacyjnych o fabularne i kompozycyjne konwencje thrillera ${ }^{8}$. Jeszcze niedawno „dreszczowce” co prawda traktowane były w badaniach jako „pozbawione wartości literackich” (jak to za Narcejakiem określa Teresa Cieślikowska ${ }^{9}$ ) wytwory czystej komercji, aktualnie jednak spogląda się na nie z dużo większą pobłażliwością, odnajdując w nich formę pod względem genologicznym „zmąconą” (termin zaproponowany przez Clifforda Geertza ${ }^{10}$ ) i do pewnego stopnia łączliwą z powieścią społeczną, polityczną czy ekologiczną i - w efekcie - przyznając jej poważne prerogatywy diagnostyczne ${ }^{11}$. Zależność jest tu dwustronna: znawcy zagadnienia nie tyle rehabilitują „krwawą szmirę” żerującą na „najniższych instynktach" odbiorców, ile reagują na zachodzące w obrębie gatunku przemiany i na niezaprzeczalny fakt, że rozwiązania charakterystyczne dla sfery suspensu odnaleźć dziś można w twórczości pisarzy niewątpliwie reprezentujących „wyższe piętro” komunikacji literackiej.

W literaturze czeskiej wśród takich, powszechnie uznawanych za kontynuatorów Ecowskiego wariantu zużytkowania szablonów thrillera, prozaików wymienia się między innymi Miloša Urbana i - nieco rzadziej - Romana Ludvę ${ }^{12}$. Obaj przynależą do grona twórców, którzy, debiutując w połowie lat dziewięćdziesiątych, zwrócili swoją uwagę w stronę fikcji metahistorycznej, swoiście jednakże pojmowanej, gdyż poszukującej materialnych śladów przeszłości w konkretny i efektywny sposób oddziałujących na współczesną rzeczywistość. W polu ich zainteresowań pozostają więc przede wszystkim dzieła sztuki i architektura, a sensacyjne fabuły kolejnych tekstów bazują na alternatywnych (ezoterycznych) metodach odczytania ich, utajnionych dla laików, sensów. W płaszczyźnie intertekstualnej pisarze kierują zatem wzrok, o fantasmagoriach Dana Browna

${ }^{8}$ Por.: „Bardzo często w thrillerze występują te same elementy strukturalne co w powieci kryminalnej, zresztą dla badaczy wiele tekstów posiada cechy wspólne zarówno dla kryminału (zbrodnia, śledztwo, intryga, odkrycie tajemnicy), jak i thrillera (epatowanie detalicznymi opisami zbrodni i towarzyszących im cierpień). Zasadniczą różnicą jest nie tylko operowanie przez thriller obrazami zbrodni, ale przede wszystkim wprowadzenie motywu zagrożenia życia protagonisty, związku poszukiwania ocalenia z rozwiązaniem tajemnicy, prowadzenie dochodzenia w tajemnicy przed opinią publiczną oraz bezpośrednie starcie z antagonistą" (B. Trocha, Między thrillerem religijnym a teologicznym - czyli zbrodnie i intrygi w świecie religii, [w:] Śledztwo w sprawie gatunków..., s. 213-214). Tzvetan Todorov uznaje thriller (roman à suspense) za formę pod względem genologicznym pośrednią - kombinującą cechy „powieści tajemnic” i roman noir (por.: T. Todorov, Poetika prózy, přel. L. Pelán, L. Valentová, Praha 2000, s. 108-110).

${ }^{9}$ Por.: T. Cieślikowska, Struktura powieści kryminalnej..., s. 72. Autorka powołuje się na monografię Pierre’a Boileau i Thomasa Narcejaka Le Roman policier (Paris 1964).

${ }^{10}$ Por.: C. Geertz, O gatunkach zmaconych (nowe konfiguracje myśli społecznej), przeł. Z. Łapiński, [w:] Postmodernizm. Antologia przekładów, red. R. Nycz, Kraków 1998, s. 214-235.

${ }^{11}$ Pisząc o specyficznych cechach tzw. skandynawskiej odmiany literatury kryminalnej i zastanawiając się nad przyczynami jej globalnej popularności, Anna Gemra zauważa, że tłem dla szwedzkich czy norweskich powieści, „nieraz szeroko rozbudowanym, są konkretne obyczaje, tradycja, systemy prawne i socjalne, uwarunkowania kulturowe. W kryminale detektywistycznym nie są one tak rozwinięte: zbrodnia jest czymś bardziej ogólnym, ma, by tak rzec, charakter uniwersalny. Popełnia się ją z zemsty, chciwości, strachu, nienawiści, gniewu, dla mniej lub bardziej enigmatycznych «wyższych celów» - ale narrator zwykle nie szuka głębszych przyczyn, zadowalając czytelnika najprostszymi wyjaśnieniami. $Z$ tych samych powodów popełnia się zbrodnie w kryminalnych powieściach sensacyjno-awanturniczych, jednak autor [...] odsłania przed czytelnikiem mechanizmy, które doprowadziły do ostatecznej tragedii. Mamy więc do czynienia z odmianą, którą można by nazwać kryminalną powieścią społeczno-obyczajową. Uatrakcyjniają ją przeżywane przez bohaterów brawurowe przygody, [...] tarapaty protagonistów ujawniają mechanizmy działania władzy, instytucji państwowych, biznesu, wymiaru sprawiedliwości, opieki medycznej, stereotypy myślowe i społeczne etc." (A. Gemra, Diagnoza rzeczywistości..., s. 52-53).

${ }^{12}$ Urban wkroczył do literatury czeskiej ,jako autor od początku łączony z trawestowaniem gatunków, polemikami z (kulturową) tradycją i grą z czytelnikiem. [...] Kontrast idealizowanej przeszłości i kondycji nowoczesnego społeczeństwa ukazywanego na skraju autodestrukcji zostaje, zwłaszcza w powieściach, których akcja toczy się w przestrzeniach autentycznych sakralnych budowli, uwypuklony dzięki uczynieniu $z$ tych historycznych uświęconych przestrzeni miejsca dziwacznych zbrodni" (I. Mindeková, M. Urban: Hastrman, [w:] V souřadnicích mnohosti. Česká literatura první dekady jednadvacátého století v souvislostech a interpretacích, red. A. Fialová, P. Hruška, L. Jungmannová, Praha 2014, s. 395). 
nie zapominając, raczej ku przeprowadzonej w Wahadle Foucaulta wiwisekcji hipotez tzw. spiskowej teorii dziejów niż ku zamieszczonym w Imieniu róży teologicznym rozważaniom, których rzetelność gwarantowana jest przez mediewistyczny autorytet naukowy autora powieści.

W literaturze czeskiej istnieje jednak odrębna, całkowicie, można by zaryzykować twierdzenie, rodzima tradycja łączenia wątków sensacyjnych z rozpatrywaniem sekretnych znaczeń artefaktów artystycznych. W roku 1873 Jakub Arbes (1840-1914), neoromantyczny prozaik i publicysta, opublikował w czasopiśmie „Lumír” opowiadanie Svatý Xaverius („Święty Ksawery”) opatrzone, dzięki sugestii Jana Nerudy, redaktora naczelnego periodyku, zaniepokojonego wywołującym hagiograficzne skojarzenia tytułem dzieła, genologicznym określeniem romaneto. Tekst ten, który z jednej strony - dzięki niezwykłej, bestsellerowej wręcz popularności, stał się wzorcem dla ukształtowania się nowej formy gatunkowej, wypada - z strony drugiej - uznać za modelowe (na gruncie czeskim) ujęcie konstrukcji fabularnej śledztwa prowadzonego w świecie sztuki. Tytuł dzieła odnosi się bowiem do umieszczonego w kościele św. Mikołaja w Pradze obrazu barokowego malarza Františka Xavera Palki (1724-1767 lub 1770) przedstawiającego męczeńską śmierć Świętego Franciszka Ksawerego, sama zaś opowieść dotyczy prób odkrycia „właściwego” znaczenia malowidła, umotywowanego błędnym czy raczej zdeformowanym odczytaniem duchowego testamentu jego autora:

Obraz umierającego Świętego Ksawerego nie został namalowany wyłącznie dla oczu i dla uszlachetnienia myśli pobożnych chrześcijan. Jest w nim więcej, niż to bywa w dziełach największych mistrzów, jest w nim coś, nad czym tysiące by z pogardą wzruszyli ramionami, co jednak mogłoby się okazać zbawienne dla milionów... Kto potrafi, choćby przez szereg lat przed obrazem tym czuwać, kto wszelkie swe myśli ku niemu skieruje po to, by tajemnicę jego wyjaśnić, kto tajemnicę tę wyjaśni, nie może dla ludzkości pozostać bezwartościowy, albowiem duch jego takiej siły i doświadczenia nabędzie, jakie konieczne są, by czynów wielkich dla korzyści całej ludzkości dokonać. Jedynej rzeczy wszak tutaj potrzeba: wytrwałości i żelaznej woli. Kto nimi uzbrojony przed obrazem czuwać będzie, tajemnicę obrazu pragnąc wyśledzić, temu Święty Ksawery skarb bezcenny objawi ${ }^{13}$.

Wychowany w duchu pozytywistycznego kultu naukowego eksperymentu bohater romaneta, koncentrując uwagę na literalnym sensie przekazu, całkowicie pomija uniwersalny, etyczny wymiar przesłania i - używając przyborów geometrycznych oraz dokonując skomplikowanych obliczeń matematycznych, stara się na podstawie kompozycji malowidła ustalić miejsce ukrycia owego, dosłownie rozumianego, „bezcennego skarbu”. Jego zdaniem bowiem, kompozycja ta stanowi zakamuflowany odpowiednik osiemnastowiecznej topografii okolic Pragi. Zainteresowanie zakodowanym w obrazie szyfrem powoli przeradza się w obsesję, ta zaś skutkować musi, w nieuchronny niejako sposób, klęską wszystkich życiowych planów protagonisty. Ich fabularnym - metaforycznym - wykładnikiem pozostaje ukazanie śmierci bohatera w wiedeńskim więzieniu, jednoznacznie, w płaszczyźnie operacji wizualizacyjnych, sugerujące podobieństwo do agonii jezuickiego męczennika ${ }^{14}$.

\footnotetext{
${ }^{13} \mathrm{~J}$. Arbes, Newtonův mozek a jiná romaneta, Praha 2002, s. 175-176.

${ }^{14}$ Por.: „Półleżąc i półsiedząc odpoczywał przyjaciel Xaverius na grubej derce na noszach. Ubrany był w więzienny strój, na piersiach poniekąd rozchełstany. Dolną część ciała okrywał stary płaszcz, spod którego wystawały bose nogi. Głowę przyjaciel przechylił do tyłu, śmiertelnie blade, zsiniałe nawet oblicze zwrócił ku błękitnemu niebu. Lewa ręka spoczywała na jego piersi, prawa, w łokciu zgięta, zwisała ku ziemi. [...] Długo stałem bez ruchu, wzroku odwrócić nie mogąc od cierpiącego człowieka; w chwili tej wydawało mi się bowiem, że kilka kroków przede mną nie widzę swego przyjaciela [...], ale kogoś z wyglądu co prawda znanego, choć z innej strony zupełnie mi obcego, a mianowicie, że widzę przed sobą umierającego świętego Ksawerego..." (tamże, s. 236-237).
} 
Arbesowski model konstrukcji narracyjnej wypracowany został, jak zgodnie twierdzą badacze, pod wpływem dogłębnego przemyślenia teorii i praktyki twórczej Edgara Allana Poego. Zamieszczone w Filozofii kompozycji autotematyczne uwagi okazały się bowiem dla pisarza „przez całe życie wielkim wzorem, który mu imponował przede wszystkim oryginalnością i niezwykłym talentem wywoływania w czytelnikach uczucia grozy za pomocą chłodnej logicznej konstrukcji"15. I właśnie owa „żelazna” logika konstrukcyjna, Arbesowi służąca przede wszystkim do udowodnienia racjonalnej, co oznacza: dającej się poznać za pomocą inte-

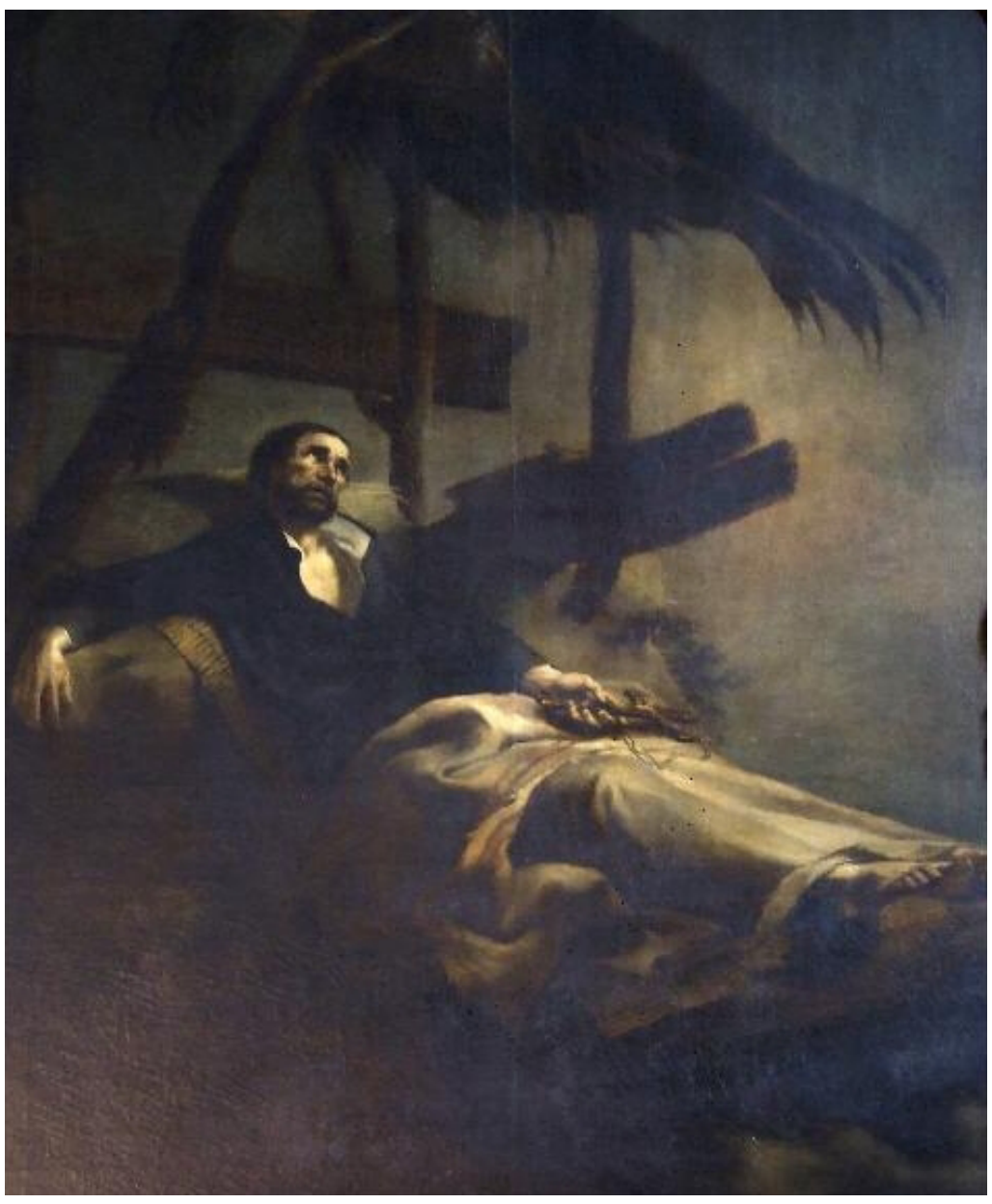

lektualnych operacji poznawczych i nieuwzględniającej żadnego „terytorium nierozstrzygalności”, pozwala ulokować romaneto wewnątrz tradycji czeskiej literatury kryminalnej.

U jej zarania leży zatem opowieść o śledztwie dotyczącym tajemnicy kryjącej się w materiale tematycznym lub w budowie świata przedstawionego dzieła sztuki. Co więcej, dzieło to ma charakter sakralny i w uświęconą przestrzeń jest integralnie wpisane. Jego pierwotny potencjał semantyczny obejmuje więc $w$ pierwszym rzędzie sensy teologiczne i/lub konfesyjne, wszelkie inne walory (z estetycznymi włącznie) spychając na dalszy plan i nadając im - w najlepszym przypadku - rangę narzędzi pomocniczych wspomagających proces docierania do usankcjonowanego intencją autorską znaczenia obrazu ${ }^{16}$. Odwrócenie hierarchii wartości i przyznanie statusu dominanty semantycznej innym elementom konstrukcyjnym wywołuje swoiste „wzmożenie” tekstowego charakteru malowidła i wymaga odmiennego typu lektury respektującej (zakładającej, nierzadko zresztą, jak to się dzieje u Arbesa, na zasadzie swoistej

${ }^{15}$ B. Dokoupil, Vliv E. A. Poea na tvorbu Jakuba Arbesa, „Sborník Prací Filozofické Fakulty Brněnské University” 1976/1977, s. 37.

${ }^{16}$ Wypada zaznaczyć, że Arbes, za pośrednictwem rozważań narratora, owych pierwszoplanowych sensów nie zaciera, choć nadaje im wymiar uniwersalny, wykraczający poza religijną wykładnię obrazu: „Znałem co prawda piękniejsze malowidła w praskich świątyniach, lecz ten właśnie obraz przyciągał moją wyobraźnię nieodpartym jakimś czarem. A przecież trudno o prostsze dzieło! Umierający człowiek! Iluż ludzi umierało już i zmarło bardziej interesująco i poetycko niż ten mąż, którego zwą Świętym Ksawerym! Wszakże gdy patrzyłem wówczas na obraz, nie przyszło mi do głowy zastanawiać się, czym ten człowiek był i w jaki sposób przyczynił się lub przeszkodził w postępie ludzkości; widziałem w nim jedynie umierającego człowieka wiary pewnej jak skała, który w wierze tej odnalazł swoje zbawienie" (J. Arbes, Newtonův mozek..., s. 154-155). 
interpretacyjnej uzurpacji) możliwość alternatywnego odczytywania sensu malarskiej reprezentacji świata:

Myślę, że po raz pierwszy spostrzegłem, w czym leży niezwykłość, by nie powiedzieć, wyjątkowość tego płótna. Z techniką malarską to nie ma nic wspólnego. Chodzi tylko o temat: czytający mnich. Przecież to jest zawarte już w tytule! Mnich, który czyta, odsłania tajemnicę obrazu! Innymi słowy, dostarcza malarzowi wskazówek, jak stworzyć płótno, które przezwycięży czas i prześlizgnie się na falach stuleci, by stać się tym, czego jedni malarze pragną, a inni w to po cichu i cierpliwie wierzą - dziełem sztuki. Ale mnich na obrazie nie maluje, czyta - a później w prawym dolnym rogu zapisuje formułę, która ma służyć malarzom. [...] Toskańska legenda dla mnie w tym momencie niepomiernie poszerzyła swoje znaczenie: tajemnica obrazu nie musi ukrywać się w malowaniu, w podejściu do niego, ale w lekturze. Ale na lekturze nie musi się zatrzymać. Może to być tylko metafora. Nieskończoność pola szachowego, która się nagle przede mną rozpostarła, była fascynująca ${ }^{17}$.

W powieści Romana Ludvy Stěna srdce („Ściana serca”, 2001) do pewnego stopnia zresztą powielającej narracyjną konstrukcję romaneta (konwencja kompozycji ramowej, zwielokrotnienie płaszczyzn narracyjnych, technika „piętrowych” przytoczeń wypowiedzi bohaterów ${ }^{18}$ ) rolę zwornika scalającego wszystkie linie fabularne odgrywa motyw obrazu, na którym według toskańskiej legendy średniowieczny twórca zamieścił ukrytą inskrypcję przekazującą „przepis” na nieprzemijającą w czasie recepcyjną (egzegetyczną) żywotność dzieła sztuki. Tekst ten trudno co prawda uznać za „pełnowartościową” powieść kryminalną, brakuje w nim bowiem większości jej obligatoryjnych wyznaczników (z motywem zbrodni na czele), ale owa „struktura domysłów”, która według Umberto Eco leży u podłoża trwałej popularności gatunku, dyryguje porządkiem sekwencji wydarzeń, a rozrzucone w przestrzeni narracji wzmianki o pisarstwie Raymonda Chandlera dodatkowo precyzują kierunek odbioru dzieła ${ }^{19}$. Samo rozwiązanie zagadki okazuje się zaskakująco banalne. Zaszyfrowana w obrazie formuła twórcza nadająca dziełom sztuki ponadczasową aktualność składa się z pięciu łacińskich słów: „PROBITAS, INGENIUM, ASSIDUITAS, GAUDIUM, EVENTUSQUE. MORS - ”(„Uczciwość, talent, pracowitość, radość i powodzenie. Śmierć -"), odsyłających ku uniwersum podstawowych wartości etycznych i rudymentar-

\footnotetext{
${ }^{17}$ R. Ludva, Stěna srdce, Brno 2001, s. 157-158.

${ }^{18}$ Sięgnięcie po taki typ kompozycji nie oznacza oczywiście automatycznie bezpośredniego nawiązania do tradycji Arbesowskiej. Jak bowiem dowodzi Mieczysław Dą̧browski: „Estetyka postmodernizmu gustuje w dwóch typach konstrukcji, które aczkolwiek nader różnią się między sobą - mają jednak wspólne źródło. Zarówno bowiem konstrukcja szkatułkowa, jak i palimpsestowa wyrastają na gruncie przeświadczenia, że oto organizacji nowej, oryginalnej nie da się już stworzyć" (M. Dąbrowski, Postmodernizm: myśl i tekst, Kraków 2000, s. 133). Brian McHale łączy zaś kompozycję szkatułkową z malarskimi iluzjonistycznymi technikami trompe l'oeil i myse en abyme (por.: B. McHale, Powieść postmodernistyczna, przeł. M. Płaza, Kraków 2012, s. 166-171, 178-184). W Ścianie serca chwyt mise en abyme zostaje zresztą przywołany za pomocą opisu szklanych bibliotecznych drzwi, na których „w nieskończoność” powiela się coraz mniejsza płaskorzeźba przedstawiająca otwartą książkę), co pozwala wzmocnić, kluczowe dla autotelicznej płaszczyzny powieści, intersemiotyczne koligacje malarstwa z literaturą.

${ }^{19}$ Schemat kryminalnego śledztwa nie musi wszak dotyczyć czynów, którym wykładnia prawna przyznaje status zbrodni czy, mówiąc oględniej, przestępstwa. Każda tajemnica, skrywająca się za niepełnym zasobem informacji i domagająca się wyjaśnienia umożliwia bowiem wykorzystanie detektywistycznych metod docierania do prawdy, a powieść kryminalna, jak przekonuje Régis Messac w pracy Le « Detective Novel » et l'influence de la pensée scientifique (1929), „to opowiadanie poświęcone metodycznemu i stopniowemu odkrywaniu tajemniczego wydarzenia za pomocą stosowania racjonalnych sposobów i ścisłego ustalania okoliczności” (cyt. za: T. Cieślikowska, Struktura powieści kryminalnej..., s. 67.)
} 
nych kategorii antropologicznych. Tajemnicy, na co zresztą zwrócili uwagę recenzenci dzieła ${ }^{20}$, nie udaje się więc w pełni wyjaśnić, choć jej podstawowe fabularne zadanie, a mianowicie skierowanie protagonisty powieści, czeskiego malarza, Josefa Hali, za młodu hołdującemu inspiracjom abstrakcjonistycznym, na „właściwą” drogę artystyczną, zostaje zrealizowane.

Protagonista ten, korzystający z pomocy licznych protektorów, staje się zarazem ofiarą manipulacji, wszyscy bowiem „dobroczyńcy” próbują wtłoczyć go w zaprogramowane a priori ramy czy matryce tożsamościowe i narzucić mu z góry określoną rolę twórcy, który, osiągając komercyjny sukces, doprowadzi jednocześnie do rehabilitacji malarstwa realistycznego, zdeprecjonowanego (wydawałoby się: nieodwołalnie) przez awangardowe eksperymenty. Opowieść o toskańskiej legendzie pełni funkcję swoistego katalizatora zrozumienia, że sztuka powinna odpowiadać duchowym i estetycznym potrzebom odbiorców, co w tym przypadku oznacza: respektować zasady figuratywności i że jedynym środkiem zrealizowania tego celu jest harmonijne przenikanie się tradycji z nowoczesnością, konkretnie zaś: aktualizacja technik malarskich sztuki gotyckiej.

Do podobnych wniosków, tym razem jednak biorąc na warsztat konwencje piętnastowiecznego malarstwa niderlandzkiego, dochodzą bohaterowie opowiadania Falzum („Falsyfikat”), stanowiącego część opublikowanego w 2012 roku pod tym samym tytułem tomu „klasycznych” narracji kryminalnych:

W gorszym przypadku [...] parę osób napisze, że ścienny współczesny obraz figuralny, wytworzony tradycyjną techniką, ma przyszłość. W przypadku lepszym europejska elita historyków sztuki objawi, że tak powiem, możliwości symbiozy starego malarstwa z nowoczesnym. A ponieważ jeden będzie chciał przebić pomysły drugiego, mimowolnie wyciągną armatę i wystrzelą ścienny współczesny obraz do XXI wieku i uczynią z niego filar sztuki na kolejne dziesięciolecia ${ }^{21}$.

W tekstach z Falsyfikatu Ludva nie stara się zbyt daleko wykraczać poza ustalone schematy prozy detektywistycznej. Bohaterami czyni dwójkę policjantów reprezentujących odmienne, ale uzupełniające się wzajemnie metody dochodzenia do prawdy (arystotelesowska logika vs. intuicja podbudowana asocjatywnym łączeniem pozornie całkowicie od siebie niezależnych zjawisk ${ }^{22}$ ), respektuje, często opisywane w badaniach, odwrócenie chronologii zdarzeń (od odnalezienia zwłok zamordowanej ofiary, przez cofanie się w przeszłość i docieranie do „istotnych dla sprawy” faktów z jej życia, po zdemaskowanie sprawcy zbrodni ${ }^{23}$ ), uwzględnia pierwszoplanową rolę przesłuchania świadków i nie pomija (choć po trosze umniejsza) znaczenia materialnych śladów i współczesnych technik

\footnotetext{
${ }^{20}$ Erik Gilk konstatuje na przykład, że: „Trzeba Ludvie przyznać, że potrafi utrzymać napięcie i ciekawość czytelnika aż do końca powieści. Tyle tylko, że tajemniczość, którą prozaik próbuje za każdą cenę zasugerować, relacjonując zachowanie większości postaci [...] wydaje się wątpliwa i dlatego czytelnik czuje się ostatecznie rozczarowany i oszukany, nie dostarcza się mu bowiem wielu ukrytych powiązań. [...] Powstaje w ten sposób paradoksalna sytuacja: na podstawie lektury czytelnik tajemnicy nie pozna, ale nie odnajdzie jej także między wierszami, ponieważ jej tam nie ma" (E. Gilk, Prozaická zasvěcení, Praha 2010, s. 38).

${ }^{21}$ R. Ludva, Falzum, Brno 2012, s. 109-110.

${ }^{22}$ Por.: „Poruczniku, logika to jest dyscyplina, która bazuje na tak zwanym wynikaniu. Z jednego faktu wynika fakt następny. Każdy człowiek jest śmiertelny. Arystoteles jest człowiekiem. Arystoteles jest śmiertelny. Wynikanie [...] Kapitanie, prawidłowe byłoby takie wynikanie? Śliwowica jest dobra. Ja piję śliwowicę. Ja jestem dobry” (tamże, s. 74, 75). Interlokutor co prawda jednoznacznie zaprzecza, ale stosowana przez Kryštofa Fridricha metoda „intelektualnego stretchingu” (jak to określa jego przełożony, Josef Rambousek) sprawdza się w praktyce śledczej o wiele lepiej niż sucha „Holmesowska” dedukcja.

${ }^{23}$ Por.: R. Caillois, Powieść kryminalna..., s. 169.
} 
kryminalistycznych. W rezultacie oferuje czytelnikowi wszystkie „znane i lubiane” gatunkowe komponenty i, zachowując hierarchię ważności, podporządkowuje im (w sensie strukturalnym) składniki drugorzędne (nieobligatoryjne), przede wszystkim, co oczywiste, te, które współgrają z prezentacją (przybliżaniem odbiorcy) społeczności malarzy, rzemieślników artystycznych, marszandów, historyków sztuki, licytatorów aukcyjnych i kustoszów wystaw. Zagadkowość zbrodni popełnianej w takim właśnie, z potocznego punktu widzenia dość hermetycznym (więc także: egzotycznym), środowisku wzrasta, przyczyniając się przy okazji do uatrakcyjnienia przebiegów fabularnych, wybrany temat pozwala zaś na przemycanie (na zasadzie zaktualizowania horacjańskiej maksymy: Aut prodesse volunt, aut delectare poetae) zasobu rzetelnych wiadomości dotyczących współczesnej (w opinii autora najwyraźniej godnej pożałowania) kondycji sztuki, która, utraciwszy autentyczny kontakt z publicznością, wegetuje na marginesie kolektywnej wyobraźni, budząc emocjonalne poruszenie już tylko wśród ekspertów i, ewentualnie, nowobogackich snobów zainteresowanych wyłącznie wysokimi cenami „galeryjnego asortymentu towarów”. Tylnymi drzwiami niejako pisarz przekazuje zatem wiarygodną historyczno-artystyczną wiedzę, nie unikając też zabiegów ekfrastycznych, co skutkuje przekształceniem narracji literackiej w miarodajne narzędzie egzegetyczne. Na tak zarysowanym tle wyeksponowane zostają, szeroko pojmowane, zagadnienia relacji zachodzących między kopią a oryginałem dzieła sztuki, odsyłające do postmodernistycznego w swej proweniencji przeświadczenia o niemożności zdefiniowania absolutnego pierwowzoru, stanowiącego punkt wyjścia nieskończonego ciągu replik, pastiszów i modyfikacji. Już w Ścianie serca postulat odtworzenia technik średniowiecznego malarstwa (inspirację stanowiła tu ikonograficzna wyobraźnia znanego czeskiego malarza, Jana Knapa) otwierał drogę ku pytaniu o granice prawa do naśladowania starych mistrzów, funkcję cytatów czy o sensowność zarzutów o wtórność i brak inwencji twórczej. Opowiadania ze zbioru Falzum wplatają te zagadnienia w sieć kryminalnych intryg (wprowadzenie tematu fałszerstwa dzieła sztuki w funkcji motywu zabójstwa nie stanowi zresztą w historii gatunku jakiegoś szczególnie odkrywczego novum), ukazując, że pojęcie falsyfikatu nie jest ostatecznie sprecyzowane (także w sensie etycznym; przywłaszczanie cudzych pomysłów nie musi bowiem koniecznie kojarzyć się z kradzieżą i plagiatem) i obejmuje swym znaczeniem nie tylko „prymitywne” zamiany

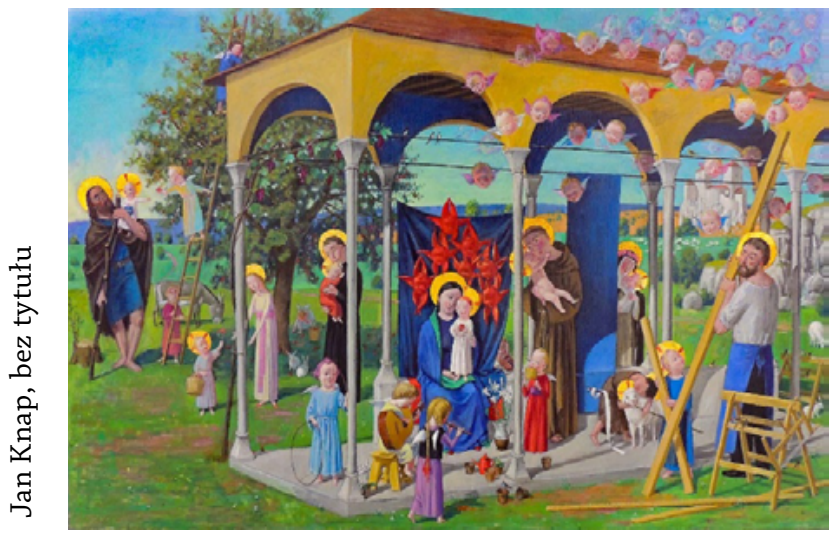
autentyków na ich idealnie wykonane repliki, ale także ćwiczenia stylizatorskie służące doskonaleniu warsztatu twórczego oraz całą gamę mniej lub bardziej dosłownych parafraz przypominających o ciągłości kulturowej tradycji. Nietrudno zresztą w tych apoteozach „wiecznego życia” dziedzictwa wielkiej sztuki rozpoznać echa podstawowych haseł teoretycznych uzasadniających (usprawiedliwiających) rozpasany eklektyzm malarstwa postmodernistycznego ${ }^{24}$.

\footnotetext{
${ }^{24}$ Zdaniem Krystyny Wilkoszewskiej, najbardziej charakterystycznym sygnałem malarskiego postmodernizmu jest to, że „po okresie neoawangardowych «dzieł» typu assemblage, fluxus, performance itp. powracają obrazy - pokryte farbą płótna, oprawione w ramy i wieszane na ścianie” (K. Wilkoszewska, Wariacje na postmodernizm, Kraków 2000, s. 196). Autorów takich obrazów badacze nazywają postmodernistami, ponieważ „odchodzą generalnie od formalizmu i abstrakcji, zwracając się, często ironicznie, w stronę mitologii, historii i narracyjności. Ich tworzywem są ikonograficzne «znaleziska» z przeszłości, które - po przywłaszczeniu - gromadzą obok siebie na obrazach. Tak jak w przypadku literackiej intertekstualności, tak i tutaj - obrazy rozmawiają ze sobą, jeden nawiązuje do innego albo do kilku innych" (tamże, s. 207-208).
} 
Problematyka falsyfikacji nie jest obca również Milošowi Urbanowi, choć w jego ujęciu kwestie usytuowania ewolucji rozwiązań artystycznych na linii innowacji i powtórzenia wywołują aksjologiczny niepokój i wątpliwości natury estetycznej. W powieści Stín katedrály. Božská krimikomedie („Cień katedry. Boska krymikomedia”, 2003) opowiadającej o serii morderstw, skutkujących profanacją przestrzeni sakralnej i redukujących najważniejszą praską świątynię do roli standardowego crime scene, pisarz, za pośrednictwem swego protagonisty, historyka sztuki, Romana Ropsa (zbieżność nazwisk z belgijskim skandalizującym symbolistą, Félicienem Ropsem, w tekście zostaje explicite wskazana), pracującego nad monografią Kamenný hvozd („Kamienny las”) poświęconą dziewiętnastowiecznej dobudowie katedry, podważa, po części przynajmniej, sens przeprowadzonej wówczas rekonstrukcji. O tym kościele jeden z bohaterów, kamieniarz Angelo Fulcanelli (nazwisko jest oczywiście również znaczące ${ }^{25}$ ), stosujący, co nie powinno dziwić, wyłącznie "oryginalne” średniowieczne techniki rzemieślnicze, mówi bowiem owemu protagoniście:

Podobnie jak ja, ma pan romantyczną duszę, człowiek pozna kolegę. A bratu romantykowi chciałbym zwrócić uwagę, że o ile stara część katedry stanowi szczytowe dzieło gotyku, o tyle cała nowa część to dzieło gotyku sfałszowanego. Pan oczywiście wie, że romantyzm w pełni rozkwitu, sam w sobie nic niewart, jast wspaniały jako zwierciadło całości. Harmonia, w tym to spoczywa. [...] To morderstwo w świątyni z tym, myślę, się wiąże ${ }^{26}$.

Stylizowana na gotyk architektura sakralna, mimo starań projektantów, „uczciwie” (jak żąda maksyma z powieści Ludvy) dążących do osiągnięcia efektu autentyku, nie jest jednak w stanie wywołać odpowiednich duchowych reakcji. Brakuje jej Benjaminowskiej aury, gdyż budowie towarzyszyły nie głęboko uwewnętrznione doświadczenia religijne, ale wyzuta z emocji ekspercka wiedza. Zbrodnia w takiej świątyni nie musi oznaczać i w przekonaniu mordercy nie oznacza profanacji, a zakończenie, w myśl reguł gatunku odpowiednio co prawda zaskakujące, nie wzbudza „litości i grozy” i nie pozwala na przeżycie katharsis. Sprawcą (czy raczej zleceniodawcą) serii zabójstw okazuje się katedralny archidiakon, ojciec Urban (znów zbieżność nazwisk nieprzypadkowa; pisarz niejednokrotnie rozrzuca swe „sygnatury” w fikcjonalnej przestrzeni kolejnych tekstów), powodowany potrzebą przywrócenia Kościołowi należnego $\mathrm{mu}$, a utraconego w wyniku postępującej ateizacji, społecznego prestiżu i rozczarowany „zdradą" bohatera, którego uważał za swego duchowego syna i spadkobiercę:

Wychowywałem cię tak, abyś się stał najlepszym świeckim między świeckimi, intelektualistą broniącym naszej sprawy. Z Kościóła dzisiaj wszyscy się śmieją. Powiedziałem więc sobie, że nadszedł najwyższy czas, aby Kościół znowu budził strach. [...] Tylko że to nie pomogło [...]. Ani te rozbite posągi, ani świnia wpuszczona na mszę, ani ta obrzydliwa rzeź, ty moich podpowiedzi nie widziałeś, nie słyszałeś ${ }^{27}$.

\footnotetext{
${ }^{25}$ Fulcanelli (1839-1953) - znany wyłącznie pod pseudonimem francuski alchemik i autor tekstów okultystycznych. Z punktu widzenia kulturowych nawiązań, eksponujących fikcjonalny charakter świata przedstawionego powieści Urbana, najistotniejsza wydaje się, niejednokrotnie zresztą przywoływana w Cieniu katedry, opublikowana w 1926 roku książka Le Mystère des Cathédrales.

${ }^{26}$ M. Urban, Stín katedrály. Božská krimikomedie, Praha 2003, s. 64.

${ }^{27}$ Tamże, s. 273, 275.
} 
Doświadczenia auratyczne towarzyszą natomiast kontemplacji walorów estetycznych kościołów zaprojektowanych przez Jana Blažeja Santiniego-Aichela (1677-1723), barokowego architekta, którego dzieła, podporządkowane misji kontreformacyjnej, w dużej mierze nadały kształt kulturowemu krajobrazowi czeskiej i morawskiej prowincji. Nie ten aspekt jego bezcennej artystycznej spuścizny jednak zainspirował pisarza do opublikowania powieści Santiniho jazyk. Román světla („Język Santiniego. Powieść światła”, 2005), ale po części zmyślone, po części zaś bazujące na dokumentarnych zapiskach (przewrotna gra, można by powiedzieć: rozgrywka między dichtung und wahrheit stanowi, najogólniej rzecz biorąc, swoisty „znak rozpoznawczy” Urbanowskiego fikcjotwórstwa), przeświadczenie, że w planach tych świątyń kryje się sekretny przekaz, którego odszyfrowanie, wymagające pogłębionej wiedzy na temat kabały, chrześcijańskiej symboliki liczb czy arkanów wolnomularstwa, pozwoli na zdobycie absolutnej mądrości. Znaczenie tego przekazu, dostępne jedynie dla wąskiego kręgu wybranych, przekazywane jest z generacji na generację i strzeżone przed profanami, także za cenę zbrodni. W świecie wtajemniczonych z niezłomną konsekwencją panuje zasada, iż "cel uświęca środki” (a uświęcenie to należy rozumieć literalnie), morderstwa popełnia się z automatyczną precyzją i całkowitą niemal atrofią wrażliwości etycznej, a ich wyrafinowana, przywodząca na myśl refleksje Thomasa de Quinceya „estetyzacja” (teatralnie upozowane ciała ofiar) ${ }^{28}$ nabiera właściwości znakowych (wycięte języki zwłok sugerują związek z kanonizacją Jana Nepomucena i jednocześnie adresatowi przekazu, bohaterowi powieści, nakazują milczenie ${ }^{29}$ ), pełni bowiem funkcję ostrzeżenia dla tych, którzy „bez upoważnienia” próbują przedrzeć się przez skomplikowany „system zabezpieczeń”. Protagonista i narrator Języka Santiniego, Martin Urmann, copywriter w renomowanej agencji reklamowej, prób takich dokonuje, motywowany jednakże nie dążeniem do osiągnięcia najwyższego poznania, ale groźbą utraty pracy. Postawiono przed nim bowiem niewykonalne (w baśniowym niemal sensie) zadanie: w ramach inicjatywy biznesowej zatytułowanej The Golden Copy Project ma sformułować uniwersalny slogan „zdolny sprzedać każdy towar”. Poszukiwanie narzędzi realizacji tego karkołomnego przedsięwzięcia inspiruje go do refleksji nad sensem milczenia (ochrony tajemnicy spowiedzi) św. Jana Nepomucena, co, w naturalny niejako sposób, wiedzie ku uwagom na temat jego, zwieńczonego kanonizacją, barokowego kultu i owocuje skierowaniem myśli ku świątyniom Santiniego, zwłaszcza zaś zbudowanemu na planie pięcioramiennej gwiazdy (pięć gwiazd symbolizuje litery w łacińskim słowie tacui - „milczałem”) kościołowi w Zelenej Horze.

\footnotetext{
${ }^{28}$ Mowa o eseju de Quinceya On Murder Considered as one of the Fine Arts („O morderstwie jako jednej ze sztuk pięknych”) z roku 1827. Explicite do pracy tej nawiązuje Ludva v opowiadaniu Gotické zvonění („Gotyckie bicie dzwonów"). Por.: R. Ludva, Falzum, s. 19.

${ }^{29}$ Por.: „W oknie [...] stał proboszcz i patrzył na nas, jego biała twarz błyszczała spoza szyby w świetle wschodzącego księżyca. Niedobrze [...] - coś jest w straszliwym nieporządku [...] Ksiądz nie ruszył się od okna nawet o milimetr i nie odwrócił głowy, kiedy wkroczyliśmy do szarego pokoju. [...] Poklepałem go po ramieniu i ten drobny, choć szybki ruch pozbawił go równowagi. Ciało niezgrabnie osunęło się na podłogę. Tak tutaj musiało leżeć, zanim ktoś je postawił w oknie. Ksiądz był omotany starannie splecionym i powyginanym drutem uformowanym w ciasną klatkę, w którą go zasznurowali, żeby się nie przewrócił. Druciany pancerz na szyi utrzywał głowę w pozycji pionowej. [...] Od drucianej pętli zaciśniętej wokół nadgarstka i bioder odwijał się do tyłu pręt przypominający ogon. Łukiem zawijał się aż ku kostkom, a stamtąd wznosił się z powrotem do brzucha, klatki piersiowej i twarzy z zakrwawioną brodą. Kończył się w otwartych ustach. [...] Ziała z nich ciemność i pustka jak z jaskini. Jak przewidywałem, morderca uciął język i zabrał ze sobą" (M. Urban, Santiniho jazyk. Román světla, Praha 2005, s. 207-208).
} 

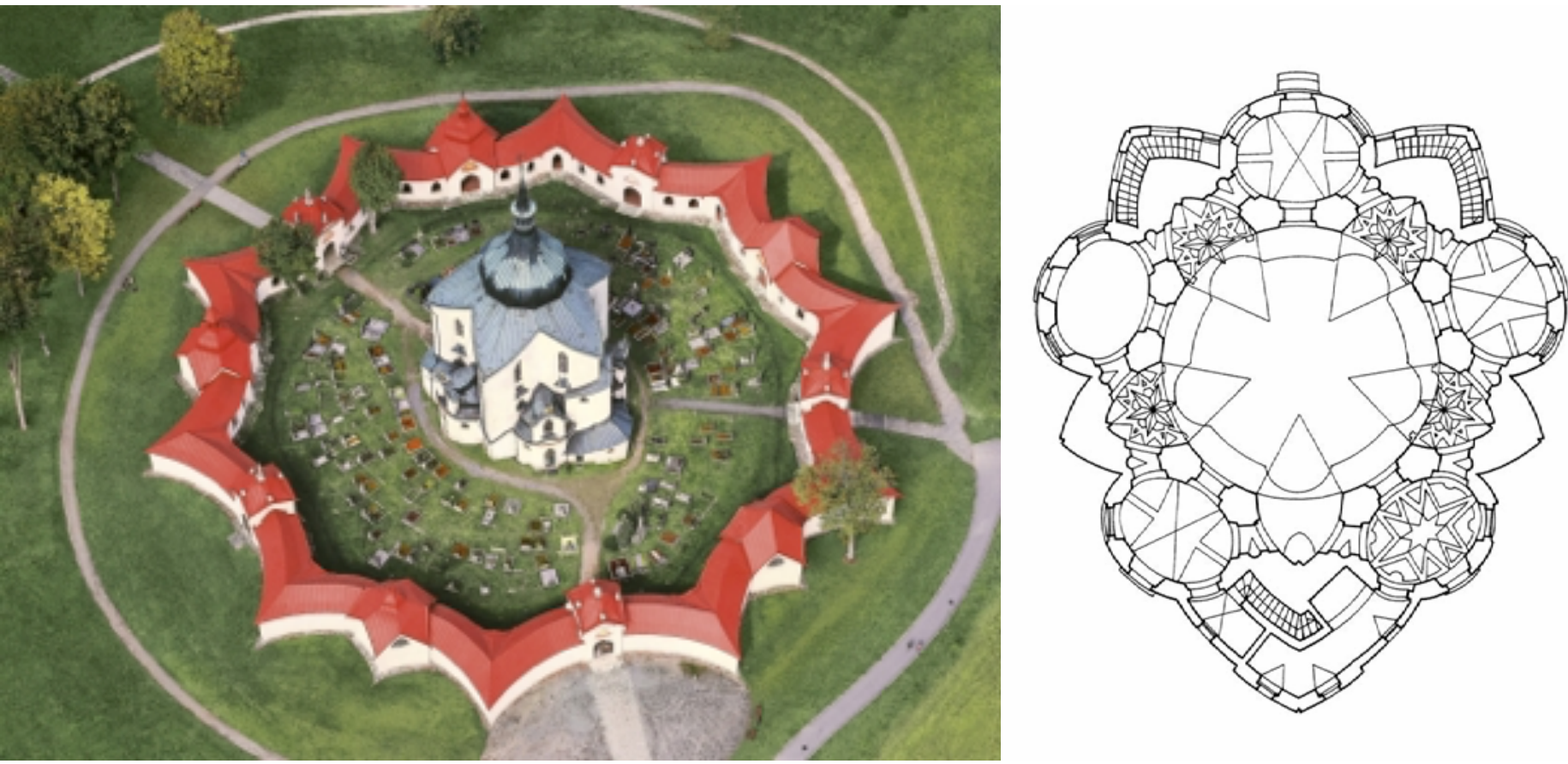

Opowieść o tych poszukiwaniach, w których Urmannowi towarzyszy w roli pomocnika i doradcy znany z Cienia katedry Roman Rops oraz zafascynowana Santinim, pragnąca restaurować jego barokowo-gotycki styl, absolwentka architektury Viktoria (reprezentująca środowisko wtajemniczonych), i które szybko przekształcają się w prywatne śledztwo, respektuje reguły konstrukcyjne thrillera, przyznając bohaterowi nieokreśloną pozycję między potencjalną ofiarą, detektywem i pośrednim sprawcą zbrodni ${ }^{30}$. Jego fabularna rola nie polega bowiem wyłącznie (jak w „klasycznej” powieści kryminalnej) na docieraniu do prawdy i zdemaskowaniu zabójcy. Wplątany wbrew własnej woli („Na początku był przypadek. Przez chwilę tak myślałem. Dziś już tego nie jestem taki pewien" ${ }^{31}$ ) w ciąg niezrozumiałych, niosących zagrożenie, wydarzeń, nieustannie obserwowany i sterowany („naznaczony”) przez dysponujących wszechwładną (w ramach tekstowej fikcji) władzą depozytariuszy wiedzy ezoterycznej, staje się obiektem operacji manipulacyjnych, z jednej strony czyniących zeń adresata wielorakich podejrzeń (na bohaterów thrillera $\mathrm{z}$ reguły nieufnie, choć z innych powodów, spoglądają zarówno spiskowcy, jak i policjanci; w Cieniu katedry funkcjonariuszka wydziału zabójstw, Klára, pełni funkcję drugiego, równorzędnego obok Romana Ropsa, narratora tekstu $\left.{ }^{32}\right)$, z drugiej strony natomiast

\footnotetext{
${ }^{30}$ Mariusz Kraska, powołując się na ustalenia Jerry’ego Palmera, wymienia „trzy zasadnicze wyróżniki decydujące o specyfice thrillera: 1 . Występowanie spisku (conspiracy), który jest postrzegany jako „nienaturalne” lub patologiczne zniszczenie przeciwnego mu, uporządkowanego świata normalności; 2. Obecność postaci walczącego ze złem bohatera (competetive hero), obdarzonego szczególnymi zdolnościami i mocą, typu samotnika, outsidera, pod tym względem przypominającego jego przeciwników; 3. Ważna rola suspensu jako podstawowego czynnika narracji" (M. Kraska, Co by było gdyby... czyli dlaczego powstała political fiction, [w:] Literatura i kultura popularna IX, red. T. Żabski, Wrocław 2000, s. 145. Badacz nawiązuje do pracy Jerry'ego Palmera Thrillers. Genesis and Structure of a Popular Genre, London 1978, s. 100).

${ }^{31}$ M. Urban, Santiniho jazyk..., s. 13.

${ }^{32} \mathrm{~W}$ przypadku thrillerów operujących motywami religijnymi (a do takich po części należą powieści Urbana) schemat fabularny, jak pisze Bogdan Trocha, „zakłada współwystępowanie dwóch typów śledztw: klasycznego, prowadzonego przez policję, zmierzającego do wykrycia sprawcy zbrodni za pomocą aparatury kryminalistycznej, oraz drugiego, komplementarnego wobec pierwszego, zmierzającego do wyjaśnienia funkcji symboli religijnych obecnych na miejscu zbrodni i określenia ich ewentualnej roli na miejscu zdarzenia" (B. Trocha, Między thrillerem religijnym a teologicznym..., s. 223).
} 
sprawdzających jego przydatność w procesie inicjacyjnym, w którym właściwe zrozumienie sensu szeregu morderstw staje się conditio sine qua non pełnej transgresji.

Powodzenie lub porażka („Ty moich podpowiedzi nie widziałeś, nie słyszałeś, wypomina Ropsowi ojciec Urban) uczestnictwa w tym procesie zależy od akceptacji prawa do morderstwa, tracącego charakter czynu nieetycznego, by zyskać dzięki temu status narzędzia ocalenia rudymentarnych wartości. Dochodzi w ten sposób do zakwestionowania jednej „z naczelnych zasad kryminału: przestępstwo jest zakłóceniem "porządku świata», lecz porządek ten w powieści kryminalnej zawsze zostaje przywrócony" ${ }^{33}$. Urban tę regułę, częściowo na zasadzie lustrzanego odbicia, odwraca: zachwianie ładu, postrzegane jako immanentna właściwość współczesności, następuje wcześniej, teraźniejszość jawi się jako domena postępującej entropii, zbrodnie stanowią zaś jej potwierdzenie lub wykładnik, ewentualnie, z innej strony patrząc, jako przestroga (wówczas, jak w Języku Santiniego, ofiary są całkowicie przypadkowe) lub „sprawiedliwa” kara za cywilizacyjne przewinienia (modernizacja utożsamia się tu z utratą duchowego wymiaru egzystencji) wskazują drogę ku swego rodzaju rekosmizacji, powrotu do wybranego momentu z przeszłości i jego konsekwentnej rekonstrukcji ${ }^{34}$. Sztuka, przede wszystkim zaś dawna architektura sakralna, zachowana do dziś w pierwotnym kształcie, potrafi wywołać kulturowe wspomnienia, aktualizujące zapoznane dziś (niesłusznie, zdaniem Urbana) pewniki aksjologiczne i przywracające im stosowną rangę metafizycznej rękojmi niezmienności rządzących funkcjonowaniem rzeczywistości praw.

Jawna dezynwoltura, z jaką Urban podchodzi do odziedziczonych po Arbesie i podpatrzonych u współczesnych sobie pisarzy szablonów genologicznych thrillera, horroru, literatury okultystycznej, gotycyzmu czy nawet dekadenckiej powieści o dandysie (Rops, miłośnik malarstwa prerafaelickiego, uważa siebie za „spóźnionego” wiktorianina ${ }^{35}$ ), nie powinna eliminować z czytelniczego (badawczego) pola widzenia wiarygodności przekazywanego za pośrednictwem sensacyjnych fabuł antymodernizacyjnego przesłania. Wszystkie źródła inter- $\mathrm{i}$ architekstualnych inspiracji potraktowane co prawda zostają przez niego z typowo postmodernistycznym ironicznym dystansem owocującym wyeksponowaniem całkowitej umowności przebiegów fabularnych, autor nie unika balansowania na granicy dobrego

\footnotetext{
${ }^{33}$ W. Bialik, Friedricha Dürrenmatta polemika z konwencją typowej powieści kryminalnej, [w:] Śledztwo w sprawie gatunków..., s. 80.

${ }^{34} \mathrm{~W}$ innych powieściach Urbana marzenie o cofnięciu się w czasie przybiera formę zrealizowanej utopii regresywnej. W Sedmikostelí („Klątwa siedmiu kościołów”, 1998) mowa jest o restytucji realiów z czternastowiecznego („przedhusyckiego”) średniowiecza, w Hastrmanie („Wodnik”, 2001) o powrocie do przedchrześcijańskich wierzeń, obyczajów i obrzędów.

${ }^{35}$ Por.: „Ci artyści nazywali siebie prerafaelitami, stworzyli bractwo, ich duchowym ojcem był Dante Gabriel Rossetti. Jako wyznawcy stylu, który panował w malarstwie przed pojawieniem się szkoły Rafaela Santiego, zaproponowali sztukę, która szokowała ówczesne społeczeństwo wspaniałością, zmysłowością i marzycielstwem, ale też naiwnością, w wieku pary i wojen kolonialnych akademickiego realizmu i pierwszych oznak z trudem przebijającego się impresjonizmu, uroczo anachronicznie prostą. Na domiar złego pozwolili sobie na coś niesłychanego: wnieść do sztuki nową odważną jakość, zrzekając się przy tym wszelkiej awangardy. Chcieli tworzyć Piękno w epoce, która je powoli, ale konsekwentnie przestawała cenić - piękno stało się dla nich bóstwem, wszystko inne było mu podporządkowane. I ja należę do tego bractwa, jestem smutnie spóźnionym wiktorianinem. Należę do ostatnich miłośników ich sztuki, przede wszystkim płócien Rossettiego, o których XX wiek ze swoimi ekspresjonizmami, kubizmami i abstrakcjami tak głupio zapomniał" (M. Urban, Stín katedrály..., s. 38).
} 
smaku („Lewą nogą stałem w żebrach zakonnika, prawa utknęła mi w miednicy mniszki”36, relacjonuje Urmann swe włamanie do kościelnej krypty, gdzie zmuszony jest stąpać po zmurszałych trumnach) i zamiast oszczędności zastosowanych środków wybiera nadmiar i rozpasanie piętrowo gromadzonych kulturowych ech i reminiscencji ${ }^{37}$, ale strategii tej nie należy identyfikować, podobnie zresztą jak kryminalnych narracji Romana Ludvy, z bezinteresowną grą z konwencjami.

Obaj twórcy proponują czytelnikowi zatem atrakcyjną pod względem lekturowym mieszankę tajemniczości, suspensu i (w przypadku Urbana) abjektywnej makabry, wzbogaconą (pogłębioną?) o „wypunktowanie” negatywnych aspektów ponowoczesnego świata, w którym rozkład tradycyjnych systemów wartości i kryzys logocentrycznej epistemologii wywołuje poczucie zagubienia i alienacji, a amorficzność rzeczywistości rodzi tęsknotę za dawnym porządkiem oraz przejrzystością schematów poznawczych i motywuje do poszukiwania porządków alternatywnych. Nieprzypadkowo jednego z bohaterów Falzum, porucznika Kryštofa Fridricha, fascynuje normatywność kolejowych rozkładów jazdy, Josef Hala ze Ściany serca przekłada ogólnikowość łacińskiej maksymy na konkret algebraicznego równania (śmierć=życie 》 śmierć=tajemnica obrazu $\rightarrow$ życie=obraz), a w protagonistach powieści Urbana zachwyt budzi zarówno niepodważalna matematyczna precyzja sakralnego budownictwa, jak i średniowieczna, chrześcijańska i kabalistyczna, mistyka liczb.

Ożywienie schematów literatury kryminalnej, dla której, jak to określa Aleksandra Kunce, pisząc o dwudziestowiecznej wrażliwości epistemologicznej: „Niepowodzenia w objęciu całości nie są sprowadzane do nieczytelnej natury świata, ale do niedoskonałości metody"38, pozwala, przynajmniej „chwilowo”, podczas doświadczenia lekturowego, wskrzesić wiarę w skuteczność „właściwie dobranej” ścieżki poznawczej. Ograniczenie reprezentacji do wyodrębnionego fragmentu świata, zamkniętego w ściśle wytyczonych ramach i poddanego drobiazgowej, semiotycznej, można by zaryzykować twierdzenie (Mariusz Czubaj pisze na

\footnotetext{
${ }^{36}$ M. Urban, Santiniho jazyk..., s. 193.

${ }^{37}$ Marcin Świerkocki podkreśla, że spokrewniony z transgresją nadmiar, jedna z konstytutywnych kategorii estetycznych postmodernizmu, „oznacza przekroczenie danej granicy w sensie wyjścia poza pojedynczy, zamknięty układ, i/albo w sensie aneksji obcych terytoriów. Nadmiar oznacza więc także wszelką postmodernistyczną mnogość: wszelkie artystyczne multiplikacje, kopie, permutacje i kombinacje, jak również wszelki pluralizm [...]. Nadmiar nie jest więc jedynie «obecnością wielu rzeczy naraz», z jednej strony oznacza bowiem «eksces», przesadę, wykroczenie (poza granice konwencji), z drugiej zaś skrajność, często «nadmierną obecność» jednej rzeczy naraz, rozmnożonej niby w gabinecie luster, a zatem uaktualniającej (i multiplikującej) jej rozmaite potencjalności" (M. Świerkocki, Postmodernizm. Paradygmat nowej kultury, Łódź 1997, s. 73).

${ }^{38} \mathrm{~A}$. Kunce, O dwudziestowiecznej wrażliwości epistemologicznej, [w:] Dwudziestowieczność, red. M. Dąbrowski, T. Wójcik, Warszawa 2004, s. 115. Badaczka przeciwstawia makrologiczne uroszczenia rozumu przypisującemu sobie zdolność do ogarnięcia owej całości bliskiemu niekonwencjonalnym metodom dochodzeniowym prezentowanym we współczesnej powieści kryminalnej „samoograniczeniu” wyrastającemu z „chęci rozbudzenia wątpienia, sygnalizowania niemocy ogarnięcia epistemologicznego, moralnego człowieka” (tamże, s. 116). Zrodzona w ten sposób wrażliwość mikrologiczna „pokazywałaby rozkład każdej całości, która drążona jest przez chaos, rozproszenie. [...] W tym sensie uwrażliwienie namysłu, które trafiło się dwudziestowieczności po jej własnym podjęciu siebie, szłoby w stronę stanu umysłu pełnego zawieszenia, ufającego wszelkim odcieniom i półtonom, rozmywających kontury, rezygnującego z klasyfikacyjnych zapędów, ufnego wobec doraźnych opisów bliskich doświadczaniu kulturowemu" (tamże).
} 
przykład o Saussure'owskiej proweniencji dedukcyjnych założeń kryminału ${ }^{39}$ ), analizie, ową iluzję zaś podtrzymuje, choć autorzy, podążając śladami Eco i Dürrenmatta, starają się (uwaga ta w większej mierze dotyczy twórczości Urbana) bezdyskusyjną efektywność linearnej kauzalności podważyć (między innymi dzięki przywołaniu kategorii przypadku lub rozważaniom na temat perwersyjnej logiki szaleństwa standardowo w thrillerach charakteryzującego seryjnych morderców), wzbudzić w odbiorcy „uzasadnioną wątpliwość” i zasugerować mu repertuar potencjalnych, obocznych interpretacji wydarzen ${ }^{40}$.

By ten efekt równoczesnego zaprzeczenia i kontynuacji gatunkowych standardów jednej z najpopularniejszych form genologicznych zrealizować, nie trzeba jednak sięgać po tematykę z dziedziny historii sztuki i „przeładowywać” narracji quasi-naukowymi wtrętami inkrustowanymi specjalistyczną terminologią do tego stopnia, że, jak to z upodobaniem czyni Urban, konieczne okazuje się opatrywanie kolejnych powieści spisami bibliograficznymi, gwarantującymi odbiorcy referencjalną rzetelność przekazywanego zasobu informacji ${ }^{41}$. Rodzi się zatem pytanie, czemu owe licznie przytaczane biogramy artystów, refleksje nad tradycyjnymi systemami ikonologicznymi i operacje ekfrastyczne służą. Odpowiedź wymaga z jednej strony przypomnienia postmodernistycznej pasji cytowania, palimpsestowości, apokryficzności

\footnotetext{
${ }^{39}$ Por.: „Historie z Sherlockiem Holmesem w roli głównej to opowieści nie tyle o śladach, ile znakach. Utwory te są manifestacją systemu semiotycznego, który w modelowej wersji został stworzony przez Ferdynanda de Saussure'a. Podstawowym założeniem uczynionym przez pioniera językoznawstwa strukturalnego była teza o jednolitej budowie znaków, które nieodmiennie zawierają w sobie element znaczący i znaczony. Ta istota znaku, w którym signifiant nierozerwalnie łączy się z signifié, jest wręcz obsesyjnie manifestowana przez Sherlocka Holmesa. [...] regułą myślenia w świecie Holmesa jest wiara w oczywistość i niepodważalność znaku" (M. Czubaj, Etnolog w Mieście Grzechu. Powieść kryminalna jako świadectwo antropologiczne, Gdańsk 2010, s. 193) Zdaniem Miroslava Petř́íčka: „Morderstwo jest w tekście w konieczny sposób «znaczące», znajduje się w pozycji stosunku signifiant do signifié, niezależnie od tego, czy owo «znaczące» rozumiemy jako znak, symbol czy funkcję (M. Petříček, Majestát zákona. Raymond Chandler a pozdní dekonstrukce, Praha 2000, s. 188).
}

${ }^{40} \mathrm{Co}$ ciekawe, badacze i recenzenci, choć w swych egzegezach unikają wpisywania powieści Urbana w obręb tradycji genologicznej literatury sensacyjnej, to jednak, po części być może podświadomie, zarzucają mu (inna kwestia, czy słusznie) brak prawidłowej logiki wynikania w konstruowaniu sekwencji fabularnych wydarzeń: „Podstawowym problemem Języka Santiniego pozostaje ornamentalność, wypływająca z braku prawidłowego porządku kauzalnego. Powieść bazująca na schemacie stopniowego odkrywania tajemnicy takiej prawidłowości zaś wymaga. Czytelnik musi bowiem autorowi uwierzyć, że nie tylko samo śledztwo, ale także kolejne kroki detektywa mają swoją logikę, że B następuje po A i oczywiście poprzedza C. Logika ta nie musi się pokrywać z logiką świata zewnętrznego, ponieważ sugestywne dzieło potrafi wytworzyć własny porządek wynikania, ale tak czy inaczej musi to być logika" (E.F. Juř́ková (P. Janoušek), Dvě a jedna je dvacet jedna aneb reklama na Santiniho aneb těžko nositelné boty, [w:] P. Janoušek, Kritikova abeceda, Praha 2009, s. 298).

${ }^{41} \mathrm{Z}$ tego punktu widzenia Urbanowskie thrillery, zestawiające ze sobą elementy i wyznaczniki heterogenicznych dyskursów, włączyć wypada w przestrzeń tzw. gatunków zmąconych, w których chodzi, jak chce Clifford Geertz, „o coś więcej niż o dziwaczne igraszki, przelotne ciekawostki czy o dobrze znany fakt, że innowacje są z definicji trudne do zaszufladkowania. Zjawisko ma charakter dostatecznie powszechny i wyrazisty, by podsunąć myśl, że jesteśmy świadkami rzeczy ważniejszej niż korekta mapy kulturalnej, niż przesunięcie kilku spornych granic [...]. Nie musimy wcale przyjąć hermetycznego poglądu na écriture jako na zbiór znaków oznaczających znaki lub bez reszty oddawać się rozkoszom tekstu aż do rozpuszczenia się jego znaczenia w naszych reakcjach, aby dostrzec, że do naszych przekonań o tym, co czytamy i piszemy, wtargnął wysoce demokratyczny klimat. Wydaje się, że cechy wiążące teksty ze sobą, stawiające je, przynajmniej na płaszczyźnie ontologicznej, na tym samym poziomie, charakteryzują je w stopniu nie mniej istotnym niż cechy wyodrębniające. Zamiast ustawionych w zwartym szyku „rodzajów naturalnych”, sztywnej, ostro zróżnicowanej pod względem cech jakościowych typologii, coraz bardziej dostrzegamy wokół nas rozległe, niemal nieprzerwane pole rozmaicie pomyślanych i różnorodnie skomponowanych wytworów, które umiemy porządkować jedynie z punktu widzenia praktycznego, relatywnego, w związku z naszymi własnymi celami. Nie chcę przez to powiedzieć, że nie dysponujemy żadnymi konwencjami interpretacyjnymi. Mamy ich więcej niż kiedykolwiek, ale są one zbudowane - a często jedynie sklecone - tak, aby pasowały do sytuacji płynnej, zróżnicowanej, zdecentralizowanej i nieuleczalnie nieskładnej" (C. Geertz, O gatunkach zmaconych (nowe konfiguracje myśli społecznej), przeł. Z. Łapiński, [w:] Postmodernizm. Antologia przekładów, red. R. Nycz, Kraków 1998, s. 215-216). 
i falsyfikacji, co kieruje uwagę w stronę tych epok w dziejach architektury i malarstwa, które taką „uświadomioną eklektyczną wtórność” wpisywały w system dopuszczalnych strategii artystycznych (nawiązując do architektonicznych rozwiązań gotyku, cytował wszakże już Santini, o dziewiętnastowiecznych budowniczych katedry św. Víta nie mówiąc), z drugiej strony zaś rozważania o mimetyzmie czy figuratywności dawnych plastycznych konwencji sprzyjają wszczęciu dyskusji poświęconej aktualności i ewentualnemu zrehabilitowaniu realistycznej reprezentacji literackiej. Intersemiotyczne powinowactwa korzystające z przekonania o dającej się zdefiniować (na przykład w płaszczyźnie funkcji) ontologicznej wspólnocie uniwersum sztuki otwierają drogę ku ponownej absolutyzacji narracyjności (jej poznawczych, estetycznych i, last but not least, komunikacyjnych walorów), w której obaj pisarze (zgodnie zresztą z postmodernistycznymi postulatami ${ }^{42}$ ) dostrzegają remedium na narastający rozdźwięk między artystami (niezależnie od tworzywa, jakim się posługują) a publicznością. Roman Ludva w Falsyfikacie przypomina zatem, że: „Sztuka jest dla ludzi, nie dla aniołów”43, a w Ścianie serca twierdzi, że malowidło, jako żywy organizm, powinno opowiadać zrozumiałą dla odbiorcy historię.

Urban z tej rehabilitacji narracyjnego potencjału wszystkich tekstów kultury wysnuwa o wiele dalej idące wnioski. W powieści Lord mord. Pražský román („Lord mord. Powieść praska”, 2008), której fabuła, tocząca się w ostatniej dekadzie XIX wieku, opowiada o seryjnym mordercy, podszywającym się pod znaną z praskiego folkloru postać widmowego Masíčka (Mięsiwka), protagonista, hrabia Arco, skrachowany arystokrata, sutener i dealer narkotyków ${ }^{44}$, w fikcyjnym świecie dzieła odgrywający typową dla thrillera rolę „detektywa z przypadku” i przedmiotu intryg spiskowców, podczas spaceru po Josefowie (żydowskiej dzielnicy Pragi w latach 1895-1914 poddanej procesowi tzw. asanacji, czyli, brutalnie rzecz ujmując, wyburzeniu; pisarz przypomina tu burzliwe dyskusje, które decyzji o przebudowie miasta towarzyszyły), relacjonuje:

Potem się z otwartej bramy wjazdowej odezwało wołanie o pomoc; błagalny, kobiecy głos, później okrzyk i nagle cicho. Wszedłem na podwórko razem z ludźmi, którzy nadchodzili z okolicznych domów. Za oknami zapalano lampy i pojawiała się w nich jedna ciemna głowa za drugą. Koło drewnianej przybudówki na drewno skupiła się grupka ubogo odzianych osób, było ich chyba ośmioro, rozmawiali podnieconymi, przestraszonymi głosami. Opodal, obok beczki na deszczową wodę, leżała w kałuży krwi jakaś dziewczyna. Na podstawie pozycji ciała i nienaturalnie obróconej głowy można było przypuszczać, że ma złamany kark ${ }^{45}$.

\footnotetext{
${ }^{42}$ Por.: „Tęsknota za klasycznym bohaterem oznacza także tęsknotę za tradycyjnie skonstruowanym opowiadaniem, interesującą, czyli poruszającą emocjonalnie fabułą i godnym zaufania narratorem, którego zdeprecjonowała awangarda i antypowieść: dlatego zapewne obserwujemy wśród pisarzy współczesnych coraz częstsze ustępstwa na rzecz realizmu i literatury pop” (M. Świerkocki, Postmodernizm..., s. 72).

${ }^{43}$ R. Ludva, Falzum, s. 172.

${ }^{44} \mathrm{Na}$ podważenie etycznych kompetencji detektywa (zwłaszcza gdy mowa o inwestygacji prywatnej lub, jak to się dzieje w przypadku hrabiego Arco, amatorskiej) zwrócił już uwagę Roger Caillois: „Poczynając od Sherlocka Holmesa, detektyw jest estetą, jeżeli nie anarchistą, bynajmniej zaś - strażnikiem moralności, a tym mniej praworządności. [...] W stosunku do społeczeństwa zajmuje, ogólnie biorąc, stanowisko jakby marginesowe, niczym czarodziej lub diabeł z dawnych bajek, który objawiał się pod postacią cudzoziemca, kupca bydła, lekarza, domokrążcy albo wreszcie kaleki, garbusa, jednookiego czy kulawego. Oblicze detektywa zawiera również - aczkolwiek w rozmaitym stopniu - coś niepokojącego i źle przyswojonego przez społeczny organizm" (R. Caillois, Powieść kryminalna..., s. 198, 199).

${ }^{45}$ M. Urban, Lord mord. Pražský román, Praha 2008, s. 144.
} 



\title{
SEOWA KLUCZOWE:
}

K R Y T Y KA NOWOCZES NOŚ C I

\author{
teorie spiskowe
}

THRILLER

estetyzacja z brod $n i$

\begin{abstract}
AbstrakT:
Reguły konstrukcyjne literatury kryminalnej doczekały się licznych opisów, opracowań i rekapitulacji. Dzisiejszy renesans tej literatury wywołuje jednak potrzebę nowych odczytań i, zwłaszcza że odbywa się w atmosferze postmodernistycznej pobłażliwości dla korzystania z popularnych schematów fabularnych i konstrukcyjnych, mieszania kategorii gatunkowych oraz predylekcji do heterogenizacji dyskursów, zmusza do zastanowienia się nad przyczynami atrakcyjności thrillera jako formy genologicznej, po którą nierzadko sięgają pisarze, by zaprezentować czytelnikowi fikcjonalną wypowiedź „pogłębioną” o diagnozowanie rozmaitych mankamentów nowoczesnego świata. W literaturze czeskiej prozaicy Roman Ludva i Miloš Urban, zainspirowani nie tylko Ecowsko-Brownowską grą z utartymi rozwiązaniami fabularnymi, lecz także tradycją rodzimą (opowiadaniami dziewiętnastowiecznego neoromantyka, Jakuba Arbesa), wpisują szablony „dreszczowca” w szeroko zakrojoną dyskusję na temat współczesnej kondycji sztuki i jednocześnie - dzięki strategii „wzmożonej” intersemiotyczności - nadają swym narracjom wymiar autotematyczny.
\end{abstract}

\section{NOtA O AUTORzE:}

Anna Gawarecka - ur. w 1963 r., dr hab., profesor nadzwyczajny UAM, bohemistka, literaturoznawca, pracownik Instytutu Filologii Słowiańskiej Uniwersytetu im. Adama Mickiewicza w Poznaniu. Główne zainteresowania naukowe: czeska literatura i kultura: imaginarium narodowe, modernizm, postmodernizm, procesy umasowienia kultury, geografia kulturowa, intersemiotyczność. Opublikowała dwie monografie (Margines i centrum. Obecność form kultury popularnej w literaturze czeskiej dwudziestolecia międzywojennego, Poznań 2012; Wygnańcy ze światów minionych, Poznań 2007) oraz kilkadziesiąt artykułów poświęconych literaturze czeskiej XIX, XX i XXI wieku. Adres e-mailowy: gawarecka@gazeta.pl. 